\title{
Helicobacter pylori infection rates in relation to age and social class in a population of Welsh men
}

\author{
F Sitas, D Forman, J W G Yarnell, M L Burr, P C Elwood, S Pedley, K J Marks
}

\begin{abstract}
The seroprevalence of IgG antibodies to Helicobacter pylori was determined using a standard enzyme linked immunosorbent assay in a population of 749 randomly selected men, aged 30-75 years, from Caerphilly, South Wales. The overall prevalence of $\boldsymbol{H}$ pylori was $56.9 \%$, increasing sharply in middle age from $29.8 \%$ in those aged $30-34$ to over $59 \%$ in those aged 45 or older $(\mathbf{p}<\mathbf{0 . 0 0 0 1})$. Age standardised seroprevalence rates were lowest in combined social class categories I and II (49.2\%), intermediate in categories IIIN and $M(57 \cdot 5 \%)$, and highest in categories IV and $V(62.2 \%)$ $(p=0.01)$. In those aged $30-34$ years, the prevalence rate for those in combined social class categories IV and V was $57.9 \%$ - double the rate for social class categories IIIM and $\mathbf{N}$ $(28.3 \%)$ and five times the prevalence rate in those in social class categories I and II $(11 \cdot 1 \%)$. These differences in the infection patterns of $\boldsymbol{H}$ pylori by social class are consistent with patterns of peptic ulcer disease and gastric cancer.
\end{abstract}

The bacteria Helicobacter pylori (formerly Campylobacter pylori) has generated considerable interest since its isolation and characterisation in 1983. ${ }^{1}$ The evidence suggests that it is a pathogen, playing an important role in the aetiology of gastritis (especially active antral gastritis), peptic ulcer disease, and possibly gastric cancer. ${ }^{2-4}$

The methods currently used for the detection of $H$ pylori infection in man include culture of the organism or its visual observation in mucosal biopsy specimens, use of an isotope based urea breath test, and detection of serum IgG antibodies. The invasiveness of the endoscopic procedures required to collect mucosal biopsy specimens and the current high costs of urea breath tests limit the epidemiological usefulness of these procedures. ${ }^{5}$ Less invasive serological techniques for the diagnosis of $H$ pylori infection by the identification of IgG antibodies, however, are now widely available. ${ }^{6}$

There have been numerous studies of subjects with upper abdominal symptoms attending endoscopy clinics ${ }^{7-11}$ and a variety of nonclinical studies using these different diagnostic methods. These population based studies have been recently reviewed, ${ }^{12}$ and typically they have included symptom free health worker staff volunteers, ${ }^{13-16}$ responders to local newspaper advertisements, ${ }^{17}$ blood donor and other healthy volunteer groups, ${ }^{818-21}$ occupational groups, ${ }^{822}$ and children. ${ }^{23}$ Only one report from Finland, examining the prevalence of $H$ pylori like organisms in biopsy specimens rather than the seroprevalence of $H$ pylori IgG antibodies, has studied randomly selected subjects. ${ }^{24}$

Clinical studies or studies of selected groups for example, blood donors - may be unrepresentative of the true picture in the population. We describe here the seroprevalence of $H$ pylori IgG antibodies in relation to age and social class in a large, randomly selected population based sample of men, aged 30-75 years, resident in the Welsh town of Caerphilly.

Subjects and methods

Plasma samples and demographic information were made available from two population based studies conducted in Caerphilly, South Wales in 1979 and in 1983 respectively. The first study, designed to look at heart disease risk factors, comprised 797 men - an $8 \%$ random sample of the 9659 men aged 30-69 years on the electoral register. ${ }^{25}$ The second study, part of a geographic correlation study, comprised 343 men aged 65-75 years - a $12 \%$ random sample of the estimated 2789 total population in this age group, selected from medical practitioner records. ${ }^{26}$ Twenty five men were included in both studies and, in 11 cases where plasma was available from both studies, the results for 1983 have been excluded. In both studies blood samples were obtained from participants and plasma fractions prepared under standardised conditions.

In both studies plasma samples for each subject were stored at $-20^{\circ} \mathrm{C}$ and had been thawed twice before analysis. $H$ pylori IgG antibody concentrations were measured with a reliable and standardised enzyme linked immunosorbent assay (ELISA) procedure. ${ }^{9}$ An ELISA optical density reading of greater than 0.7 , which corresponded to an IgG antibody titre of $10 \mu \mathrm{g} / \mathrm{ml}$, was considered as positive evidence of $H$ pylori infection. This cut off showed both sensitivity and specificity of over $95 \%$ in detecting $H$ pylori infection on the basis of culture from gastric biopsy material, histopathology, and the rapid urease test. ${ }^{10}$

All analyses used five year age groupings 30-4, $35-9,40-4, \ldots$ 70-75 years. Categorisation of social class was based on the current or most recent occupation of each subject obtained by questionnaire and based on the standard UK divisions into six major groupings: I, II, IIIN, IIIM, IV, and V. ${ }^{27}$ Because the combination of nine age and six social class groups resulted in specific age class groups with no subjects, we combined social class categories as follows: I and II, IIIN and M, and IV and V. Prevalence rates for age and social class categories were indirectly standardised for each other. The significance of linear trends of infection, by age or social class 
TABLE I Age specific prevalence rates for Helicobacter pylori IgG antibodies among 749 Caerphilly men

\begin{tabular}{|c|c|c|c|c|c|c|c|}
\hline \multirow{2}{*}{$\begin{array}{l}\text { Age } \\
\text { group }\end{array}$} & \multirow[b]{2}{*}{ No } & \multirow{2}{*}{$\begin{array}{l}\text { No } \\
\text { positive } \\
\text { for } \\
\text { H pylori }\end{array}$} & \multicolumn{2}{|c|}{ Crude data } & \multicolumn{2}{|c|}{ Adjusted for social class } & \multirow{2}{*}{$\begin{array}{l}\text { Median } \\
O D\end{array}$} \\
\hline & & & $(\%)$ & $(95 \% C I)$ & $(\%)$ & $(95 \% C I)$ & \\
\hline $\begin{array}{l}30-34 \\
35-39 \\
40-44 \\
45-49 \\
50-54 \\
55-59 \\
60-64 \\
65-69 \\
70-75\end{array}$ & $\begin{array}{r}106 \\
81 \\
87 \\
62 \\
84 \\
68 \\
42 \\
131 \\
88\end{array}$ & $\begin{array}{l}31 \\
33 \\
43 \\
45 \\
56 \\
44 \\
29 \\
79 \\
66\end{array}$ & $\begin{array}{l}29 \cdot 3 \\
40 \cdot 7 \\
49 \cdot 4 \\
72 \cdot 6 \\
66 \cdot 7 \\
64 \cdot 7 \\
69 \cdot 1 \\
60 \cdot 3 \\
75 \cdot 0\end{array}$ & $\begin{array}{l}(23 \cdot 1-35 \cdot 4) \\
(33 \cdot 1-48 \cdot 3) \\
(41 \cdot 9-56 \cdot 9) \\
(64 \cdot 7-80 \cdot 5) \\
(59.5-73 \cdot 9) \\
(56 \cdot 6-72 \cdot 8) \\
(59 \cdot 1-79 \cdot 0) \\
(54 \cdot 3-66 \cdot 3) \\
(68 \cdot 5-81 \cdot 5)\end{array}$ & $\begin{array}{l}29 \cdot 8 \\
42 \cdot 1 \\
48 \cdot 8 \\
74 \cdot 5 \\
66 \cdot 2 \\
63 \cdot 4 \\
69 \cdot 2 \\
59 \cdot 4 \\
73 \cdot 9\end{array}$ & $\begin{array}{l}(23 \cdot 5-36 \cdot 0) \\
(34 \cdot 3-49 \cdot 7) \\
(41 \cdot 3-56 \cdot 3) \\
(66 \cdot 5-82 \cdot 0) \\
(58 \cdot 9-73 \cdot 3) \\
(55 \cdot 2-71 \cdot 6) \\
(59 \cdot 2-79 \cdot 1) \\
(53 \cdot 4-65 \cdot 4) \\
(67 \cdot 3-80 \cdot 5)\end{array}$ & $\begin{array}{l}0.39 \\
0.58 \\
0.68 \\
0.91 \\
0.82 \\
1.00 \\
0.90 \\
0.81 \\
0.93\end{array}$ \\
\hline Total & 749 & 426 & 56.9 & $(54 \cdot 4-59 \cdot 4)$ & & & $0 \cdot 78$ \\
\hline \multicolumn{2}{|c|}{$\begin{array}{l}\chi^{2} \text { trend }(\mathrm{ldf}) \\
\mathrm{p} \text { value }\end{array}$} & & \multicolumn{2}{|l|}{$\begin{array}{l}46 \cdot 7 \\
<0.0001\end{array}$} & \multicolumn{2}{|c|}{$\begin{array}{l}42 \cdot 3 \\
<0.0001\end{array}$} & \\
\hline
\end{tabular}

$\mathrm{OD}=$ optical density

TABLE II Prevalence rates for Helicobacter pylori IgG antibodies in relation to social class

\begin{tabular}{|c|c|c|c|c|c|c|c|}
\hline \multirow{2}{*}{$\begin{array}{l}\text { Social } \\
\text { class } \\
\text { grouping }\end{array}$} & \multirow[b]{2}{*}{ No } & \multirow{2}{*}{$\begin{array}{l}\text { No } \\
\text { positive } \\
\text { for } \\
\text { H pylori }\end{array}$} & \multicolumn{2}{|c|}{ Crude data } & \multicolumn{2}{|c|}{ Adjusted for age } & \multirow{2}{*}{$\begin{array}{l}\text { Median } \\
O D\end{array}$} \\
\hline & & & $(\%)$ & $(95 \% C I)$ & $(\%)$ & $(95 \% C I)$ & \\
\hline $\begin{array}{l}\text { I \& II } \\
\text { IIIM \& N } \\
\text { IV \& V }\end{array}$ & $\begin{array}{l}158 \\
420 \\
171\end{array}$ & $\begin{array}{r}75 \\
242 \\
109\end{array}$ & $\begin{array}{l}47 \cdot 5 \\
57 \cdot 6 \\
63 \cdot 7\end{array}$ & $\begin{array}{l}(41 \cdot 9-53 \cdot 1) \\
(54 \cdot 2-61 \cdot 0) \\
(58 \cdot 6-68 \cdot 9)\end{array}$ & $\begin{array}{l}49 \cdot 2 \\
57 \cdot 5 \\
62 \cdot 2\end{array}$ & $\begin{array}{l}(43 \cdot 6-54 \cdot 8) \\
(54 \cdot 1-60 \cdot 9) \\
(57 \cdot 0-67 \cdot 4)\end{array}$ & $\begin{array}{l}0.68 \\
0.77 \\
0.84\end{array}$ \\
\hline Total & 749 & 426 & $56 \cdot 9$ & $(54 \cdot 4-59 \cdot 4)$ & & & \\
\hline \multicolumn{2}{|c|}{$\begin{array}{l}\chi^{2} \text { trend }(1 \mathrm{df}) \\
\mathrm{p}=\end{array}$} & & $\begin{array}{l}8 \cdot 8 \\
0 \cdot 003\end{array}$ & & $\begin{array}{l}6 \cdot 3 \\
0 \cdot 01\end{array}$ & & \\
\hline
\end{tabular}

(adjusted for each other) and statistical interaction between age and social class were assessed using the Generalised Linear Interactive Modelling statistical package. ${ }^{28}$

\section{Results}

COMPLETENESS OF INFORMATION

Out of the 797 men selected, $711(89.2 \%)$ participated in the first Caerphilly study. ${ }^{25}$ For 124 subjects there was no plasma left over for this analysis and an additional 24 subjects had no social class information available. Thus the total number of subjects available for this study was $711-(124+24)=563,70.6 \%$ of the original sample. In the second study, ${ }^{26} 246$ out of the 343 men participated $(71 \cdot 7 \%)$ and plasma samples were available for $197,57 \cdot 4 \%$ of the original sample. Omission of the 11 men for whom plasma samples were available in both the 1979

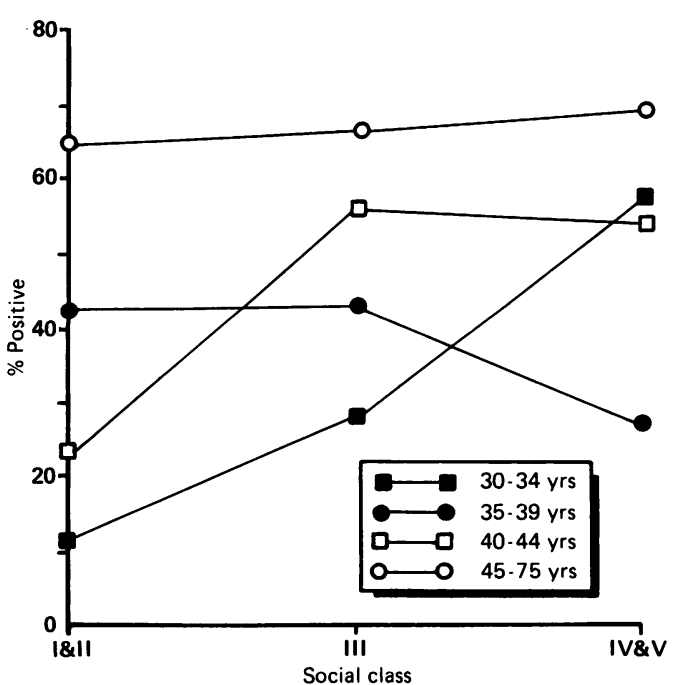

and 1983 studies effectively reduced the number of subjects in the latter from 197 to 186.

By combining the two studies, plasma and information on both age and social class was available for $(563+186) 749$ subjects, which represents $67 \%$ of the original sample of $(797+$ $343-25) 1115$. There was no difference in the social class distribution $\left(\chi^{2}=4.6 ; p=0.5\right)$ or the age distribution $\left(\chi^{2}=8 \cdot 1 ; p=0 \cdot 4\right)$ between those who had plasma available and those who did not.

PREVALENCE OF H PYLORI

Table I shows the crude and social class adjusted prevalence rates of $H$ pylori antibody for the age categories 30-34, 35-39, . . . 70-75 years. Approximately $30 \%$ of the population aged $30-34$ years, $(29 \cdot 8 \%$ adjusted for social class) had a positive antibody titre for $H$ pylori. This prevalence increased steeply with age until 45-49 years, after which it remained constant at about $60 \%$ or greater. A test for linear trend with age (adjusted for social class) was statistically significant $\left(\chi^{2}\right.$ trend $\left.=42 \cdot 3 ; \mathrm{p}<0.0001\right)$. Comparison of median optical density values by age (and social class) showed a similar pattern to the results using a dichotomous categorisation of $H$ pylori infection. Median optical density values were lowest in the youngest age group (30-34 years) and increased with age, levelling off in those older than 45 years.

The distribution of $H$ pylori infection in relation to social class is shown in Table II. The age standardised rates for $H$ pylori prevalence were lowest in social class categories I and II (49.2\%; $\mathrm{I}=33.3 \% \mathrm{II}=50.9 \%$ ), intermediate in categories IIIN and $M(57.5 \%$; IIIN $=50.0 \%$; IIIM= $59.1 \%$ ) and highest in categories IV and V $(62 \cdot 2 \% ; \mathrm{IV}=65 \cdot 6 \% \mathrm{~V}=58 \cdot 7 \%)$. A test for linear trend of increasing prevalence rates with decreasing social class was statistically significant after adjusting for age $\left(\chi^{2}=6 \cdot 3 ; p=0.01\right)$. The median optical density value for those in social class IV and V was higher $(0 \cdot 84)$ when compared with that for social class I and II $(0.68)$, while those in social class IIIM and $\mathrm{N}$ showed an intermediate value $(0 \cdot 77)$.

Prevalence rates by social class on an age specific basis are shown in the Figure. Because there were no differences in age groups above 45 years and for the sake of simplicity, men aged 45-75 years are shown as a single age category. There were large differences within the youngest age group (30-34 years), the rate in social class categories IV and V (57.9\%) being more than double that of categories IIIN and $M(28 \cdot 3 \%)$, and about five times higher than that in categories I and II (11·1\%). In those aged 35-39 years and 40-44 years, social class differences were present but not with any particular trend. Prevalences in those aged over 45 years were very similar in all class categories.

When an interaction term (for age and social class) was added to the model examining the age adjusted trend in social class, there was no significant improvement in fit $\left(\chi^{2}=11 \cdot 43, \mathrm{df}=8\right.$, $\mathrm{p}=0 \cdot 2)$. Having cxamined the data, howcver, wc also fitted a model in which those aged 45 years and over were combined into a single age category. In this post hoc analysis, addition of the 
interaction term resulted in a significant improvement in fit $\left(\chi^{2}=11 \cdot 04, \mathrm{df}=3, \mathrm{p}=0 \cdot 01\right)$.

\section{Discussion}

Although based on plasma collected for other purposes, this is the first study in which the prevalence of $H$ pylori antibodies has been measured in a large population selected at random. Full data were available for only $67 \%$ of those selected but the refusal rate was only $16 \%$ (183 of 1115 ) as the other $17 \%$ of the original sample of 1115 represent those for whom no plasma (159 subjects) or social class (24 subjects) information was available. The similarity in age and social class distribution between those who did and those who did not have plasma available, the high participation rate, and the random sampling technique mean that out data were relatively free from the biases associated with volunteer and other selected groups.

All the plasma samples were subjected to two freeze thaw cycles before our investigation. We know of no evidence that this detrimentally affects the performance of the ELISA but in any case, any damage caused by these cycles would have affected the whole population and not be biased towards any subgroup.

Our results showed a high prevalence of $H$ pylori infection in this population and a relation with both age and social class. Overall, 56.9\% (95\% CI 54.4-59.4) of the 749 men in Caerphilly showed positive evidence of infection with $H$ pylori and, as in all other similar studies, there was a pronounced association with age. Prevalence increased sharply between 30 and 45 years and over the age of 45 years the proportion infected was $67 \cdot 1 \%(95 \%$ CI $64 \cdot 1-70 \cdot 2)$.

Our prevalence figures are higher than those from other studies of non-clinical populations (see Table III) excepting a study from Algeria and the Ivory Coast in which $80-90 \%$ of adults

TABLE III Studies with more than 100 participants, assessing the prevalence of Helicobacter pylori in non-clinical populations

\begin{tabular}{|c|c|c|c|c|c|c|c|}
\hline Authors & Ref & Year & $\begin{array}{l}\text { Country, } \\
\text { population }\end{array}$ & Sampling method & No & $\begin{array}{l}\text { Age range } \\
\text { (years) }\end{array}$ & $\begin{array}{l}\text { Sero- } \\
\text { prevalence } \\
(\%)\end{array}$ \\
\hline Jones et al & 8 & 1986 & UK & $\begin{array}{l}\text { Non-GI volunteers, } \\
\text { screening clinics }\end{array}$ & 607 & $6-90$ & $20 \cdot 6$ \\
\hline Morris et al & 18 & 1986 & $\mathrm{~N}$ Zealand & $\begin{array}{l}\text { Blood donors, } \\
\text { Syphilis screening } \\
\text { sera, occupa- } \\
\text { tional groups }\end{array}$ & $\begin{array}{l}483 \\
251\end{array}$ & $\begin{array}{l}15-70 \\
10-80\end{array}$ & $\begin{array}{l}36 \cdot 2 \\
16 \cdot 7\end{array}$ \\
\hline $\begin{array}{l}\text { Wyatt et al } \\
\text { Siurala et } a l^{\star}\end{array}$ & $\begin{array}{l}20 \\
24\end{array}$ & $\begin{array}{l}1988 \\
1988\end{array}$ & $\begin{array}{l}\text { UK } \\
\text { Finland }\end{array}$ & $\begin{array}{l}\text { Blood donors } \\
\text { Random }\end{array}$ & $\begin{array}{l}247 \\
179\end{array}$ & $\begin{array}{l}20-60 \\
\text { Adult }\end{array}$ & $\begin{array}{l}30 \cdot 0 \\
A=49 \cdot 0 \\
B=53 \cdot 0\end{array}$ \\
\hline \multirow[t]{4}{*}{ Dwyer $e t$ al } & 12 & 1989 & $\begin{array}{l}\text { Australia } \\
\text { White }\end{array}$ & $\begin{array}{l}\text { Lab staff, blood } \\
\text { donors }\end{array}$ & 154 & $10-59$ & $14 \cdot 6$ \\
\hline & & & $\begin{array}{l}\text { N Australia } \\
\text { Aborigine }\end{array}$ & $\begin{array}{l}\text { Syphilis, hepatitis } \\
\text { B sera }\end{array}$ & 274 & $10-59$ & $0 \cdot 7$ \\
\hline & & & S Australia & $\mathrm{N} / \mathrm{S}$ & 285 & $10-59$ & $50 \cdot 0$ \\
\hline & & & $\begin{array}{l}\text { S Australia } \\
\text { Vietnamese }\end{array}$ & $\begin{array}{l}\text { Immigration health } \\
\text { centres }\end{array}$ & 190 & $20-59$ & $18 \cdot 0$ \\
\hline \multirow[t]{2}{*}{ Marshall et al } & 19 & 1989 & $\begin{array}{l}\text { USA } \\
\text { Virginia }\end{array}$ & Blood donors & 510 & $20-65$ & \\
\hline & & & $\begin{array}{l}\text { White } \\
\text { Black }\end{array}$ & & & & $\begin{array}{l}12 \cdot 0 \\
36 \cdot 0\end{array}$ \\
\hline $\begin{array}{l}\text { Fitzgibbons } \\
\text { et al } l^{\star}\end{array}$ & 17 & 1989 & USA & Healthy volunteers & 116 & $19-91$ & $A=31 \cdot 0$ \\
\hline \multirow[t]{2}{*}{ Megraud et al } & 29 & 1989 & Algeria & Blood donors & 277 & $\begin{array}{r}0-10 \\
\text { Adult }\end{array}$ & $\begin{array}{l}45 \cdot 2 \\
80-90\end{array}$ \\
\hline & & & $\begin{array}{l}\text { Ivory } \\
\text { Coast }\end{array}$ & Cluster sample & 374 & $\begin{array}{r}0-10 \\
\text { Adult }\end{array}$ & $\begin{array}{l}55 \cdot 2 \\
80-90\end{array}$ \\
\hline This study & & 1990 & UK, Wales & Random & 749 & $30-75$ & $56 \cdot 9$ \\
\hline
\end{tabular}

^Based on histopathology A (antral) B (fundal/body) biopsies; N/S = not stated; GI = gastrointestinal were positive. ${ }^{29}$ It is, however, difficult to make comparisons between studies without making allowance for the different analytical techniques, the age composition of other study populations, and the selection effects of using non-random samples. In the two other British studies, from Manchester ${ }^{8}$ and Leeds, ${ }^{20}$ the prevalences of infection above the age of 50 years (by which time there should be relatively little effect of age) were $45.9 \%(95 \% \mathrm{CI} 40 \cdot 3-51 \cdot 5)$ and $50 \%(95 \%$ CI 38.9-61.1) respectively compared with our figure of $66 \cdot 3 \%(95 \% \mathrm{CI} 63 \cdot 1-69 \cdot 6)$. In a Finnish study of healthy blood donors the prevalence of infection in those over 50 years was over $50 \%{ }^{21}$

Although some of the differences between studies were likely to be a result of methodological differences - for example different assays and selection procedures - it is also possible that infection rates in Caerphilly were genuinely raised. There are no data to assess whether gastritis prevalence in Caerphilly was correspondingly high but it may be noted that the mortality rate for gastric cancer in the period 1968-78 was 138 (England and Wales $=100$ ) and this part of Wales has traditionally been associated with high gastric cancer mortality. ${ }^{263031}$ In the same period, male mortality rates from gastric and duodenal ulcer in this area of Wales were at and below the national average respectively ${ }^{31}$; but mortality rates are unlikely to reflect the true incidence of peptic ulcer at this period of time.

Our data show an inverse relation between prevalence of $H$ pylori infection and social class that is, infection rates were highest in the lowest social class categories. Examination of the Figure indicates that this trend with social class is predominant in two of the three youngest five year age groups. A test for statistical interaction between age and social class was not, however, significant without the post hoc combination of those aged $45-75$ years into a single category. As this latter analysis was conducted after examining the data, the interaction requires confirmation in other independent studies. Also, even after the combination of social classes, the numbers in each age class category became quite small. At this stage, therefore, undue emphasis should not be placed on the social class effect being specific to young men. If confirmed, however, it would indicate that the higher social class groups are potentially protected from or are less susceptible to infection at a young age. It is not possible to say whether young men in the high social class groups will remain free of infection as they become older - that is, a cohort effect - or whether by the age of 50 they will have the same prevalence of infection as those in lower class groups. Also, other reports from South America, ${ }^{2332}$ Africa, ${ }^{2933}$ and USA $^{34}$ have shown a similar high prevalence of $H$ pylori antibodies among poor population groups, particularly at young ages.

Data for England and Wales for the last two to three decades show an inverse relation between both gastric and duodenal ulcer prevalence and social class. In general terms, peptic ulcer is about twice as common in those of low social class. ${ }^{35-37}$ Low social class has also been a strong determinant of gastric cancer in England and 
Wales for over 50 years ${ }^{38}$ and this may be partly related to the high prevalence of $H$ pylori infection and associated gastritis in these men in early life. Correa $e^{2} a^{39}$ have shown in Colombia that the prevalence of antral atrophic gastritis at young ages is a major factor distinguishing populations at high risk of gastric cancer from those at low risk. If $H$ pylori associated gastritis progresses to chronic atrophic gastritis then our results are in keeping with the findings in Colombia.

In summary, our results have shown that the prevalence of $H$ pylor infection can be very high, even in western countries. Infection rates showed significant differences between age and social class groupings. There is some evidence that the age of acquisition of infection may be related to social class but further studies in areas of varying peptic ulcer and gastric cancer incidence are required to confirm this finding.

We thank Dr Valerie Beral, Sir Richard Doll, Dr Tim Key, Dr Sarah Darby, and Dr Paul Silcocks for suggesting improvements to the manuscript, Dr Diane Newell for providing us with $H$ pylor acid extract antigen, and Miss Sarah Jones for typing the manuscript. We are grateful for the support of Professor Richard manuscript. We are grateful for the support
Smallwood in the early stages of this work.

1 Marshall BJ, Warren JR. Unidentified curved bacilli in the stomach of patients with gastritis and peptic ulceration. Lancet 1984 ; i: 1311-5.

2 Graham DY, Klein PD. Campylobacter pyloridis gastritis: the past, the present, and speculations about the future. past, the present, and speculation

3 Correa P, Ruiz B. Campylobacter pylori and gastric cancer. In Rathbone BJ, Heatley RV (eds). Campylobacter pylori and gastroduodenal disease. Oxford: Blackwell Scientific, 1989 $139-45$.

4 Smallwood R. Is Campylobacter a pathogen? In: Snook JA ewell DP, eds. Recent topics in gastroenterology. Oxford. Blackwell Scientific, 1990; 45-58.

5 Megraud F. Comparison of different tests for Campylobacter pylori. Scand F Gastroenterol 1988; 23 (Suppl 142): 64-8.

6 Newell DG, Rathbone BJ. The serodiagnosis of Campylobacter pylori infection. Serodiagnosis Immun Infect Dis 1989; 3: 1-6.

7 Booth L, Holdstock G, MacBride H, et al. Clinical importance of Campylobacter pyloridis and associated serum IgG and IgA of Campylobacter pyloridis and associated serum IgG and IgA antibody responses in patients undergoing upper

8 Jones DM, Eldridge J, Fox AJ, Sethi P, Whorwell PJ. Antibody to the gastric Campylobacter-like organism ("Campylobacter pyloridis") - clinical correlations and distribution in the normal population. $\mathcal{F}$ Med Microbiol 1986 22: $57-62$

9 Steer HW, Hawtin PR, Newell DG. An ELISA technique for the serodiagnosis of Campylobacter pyloridis infection in patients with gastritis and benign duodenal ulceration. Serodiagnosis. Immunotherapy. 1987; 1: 253-9.

10 Newell DG, Bell GD, Weil J, Jones P, Grant P, Harrison G The effect of treatment on circulating anti-Helicobacter pylori antibodies - a two year follow-up study. In: Malfertheimer $\mathrm{P}$, Ditschuneit $\mathrm{H}$, eds. Helicobacter pylori, gastritis and peptic ulcer. Berlin: Springer Verlag, 1990: 172-5.

11 Musgrove C, Bolton FJ, Krypczyk AM, et al. Campylobacter pylori: clinical, histological, and serological studies. $\mathcal{F}$ Clin

12 Dwyer B, Kaldor J, Tee W, Raios $K$. The prevalence of Campylobacter pylori in human populations. In: Rathbone BJ, Heatley RV, eds. Campylobacter pylori and gastroduodenal disease. Oxford: Blackwell Scientific, 1989: 190-6.

13 Barthel JS, Westblom TU, Harvey AD, Gonzalez F, Everett ED. Gastritis and Campylobacter pylori in healthy, asymptomatic volunteers. Arch Intern Med 1988; 148: 1149-51.
14 Burnett RA, Forrest JAH, Girdwood RWA, Fricker CR Campylobacter-like organisms in the stomach of patients and healthy individuals. Campylobacter pylori. Lancet 1988; 1349.

15 Dooley CP, Fitzgibbons P, Cohen H, et al. Prevalence and distribution of Campylobacter pylori in an asymptomatic population. Gastroenterology 1988; 94 (Suppl): Als6.

16 Graham DY, Klein PD, Opekun AR, et al. Epidemiology of Campylobacter pylori infection: ethnic considerations. Scand Campylobacter pylori infection: ethnic cons
f Gastroenterol 1988; 23 (Suppl 142): 9-13.

17 Fitzgibbons PL, Dooley CP, Cohen H, Appleman MD Prevalence of gastric metaplasia, inflammation, and Campy lobacter pylori in the duodenum of members of a norma population. Am F Clin Pathol 1988; 90: 711-4.

18 Morris A, Nicholson G, Lloyd G, Haines D, Rogers A, Taylor D. Seroepidemiology of Campylobacter pyloridis. NZ Med $\mathcal{F}$ 1986; 99: 657-9.

19 Marshall BJ, Caldwell SH, Yu ZJ, Darr F, Change T, McCallum RW. Prevalence of $C$ pylori and history of upper GI investigation in healthy Virginians. Gastroenterology 1989; 96 (Suppl): A321.

20 Wyatt JI, Rathbone BJ. The role of serology in the diagnosis of Campylobacter pylori infection. Scand $\mathcal{f}$ Gastroenterol 1989 . 24 (Suppl 160): 27-34.

21 Kosunen TU, Hook J, Rautelin HI, Myllyla G. Age dependan increase of Campylobacter pylori in blood donors. Scand $\mathcal{Y}$ Gastroenterol 1989; 24: $110-4$

22 Vaira D, Holton J, Londei M, et al. Campylobacter pylori in abattoir workers: is it a zoonosis? Lancet 1988; ii: 725-6.

23 Klein PD, The Gastrointestinal Physiology Working Group of Cayetano Heredia and the Johns Hopkins Universities, Graham DY, Opekun AR, Sekeley S, Evans DG, Evans DJ. High prevalence of Campylobacter pylori (CP) infection in poor and rich Peruvian children determined by ${ }^{13} \mathrm{C}$ urea breath test. Gastroenterology 1989; 96 (Suppl): A260.

24 Siurala M, Sipponen P, Kekki M. Campylobacter pylori in sample of Finnish population: relations to morphology and sample of Finnish population: relations to morphology
functions of the gastric mucosa. Gut 1988; 29: 909-15.

25 The Caerphilly \& Speedwell Collaborative Group. Caerphilly and Speedwell collaborative heart disease studies. and Speedwell collaborative heart disease

26 Burr ML, Samloff IM, Bates CJ, Holliday RM. Atrophic gastritis and vitamin $C$ status in two towns with different stomach cancer death-rates. Br $\mathcal{F}$ Cancer 1987; 56: 163-7.

27 Office of Population Censuses and Surveys. Classification of occupations. Government Statistical Services. London: HMSO, 1980.

28 Healy MJR. GLIM: An introduction. Oxford: Clarendon Press, 1988.

29 Megraud F, Brassens-Rabbe M-P, Denis F, Belbouri A, Quynh Hoa D. Seroepidemiology of Campylobacter pylor infection in various populations. $\mathcal{F}$ Clin Microbiol $1989 ; 27$. 1870-3.

30 Craven JL, Baum M, West RR. Variations in gastric cancer incidence in South Wales. Clin Oncol 1979; 5: 341-51.

31 Gardner MJ, Winter PD, Barker DJP. Atlas of mortality from selected diseases in England and Wales 1968-1978. Chichester: John Wiley, 1984

32 Guittierez F, Sierra Gomez MC, Camargo H. Campylobacter pylori in chronic environmental gastritis and duodenal ulcer patients. Gastroenterology 1988; 94 (Suppl): A163.

33 Lachlan GW, Gilmour HM, Jass JJ. Campylobacter pylori in central Africa. $\mathrm{BrMed} \mathcal{F} 1988 ; 296: 66$

34 Dehesa M, Dooley CP, Cohen H, Fitzgibbons P, Perez-Perez GI, Blaser MJ. High prevalence of Campylobacter pylori (CP) in an asymptomatic hispanic population. Gastroenterology 1989; 96 (Suppl): A115.

35 Langman MJS, Logan RFA. Gastrointestinal disease. In: Holland WW, eds. Oxford textbook of public health. Oxford: Oxford University Press, 1984: 167-71.

36 Office of Population Censuses and Surveys. Occupational mortality 1970-1972 Decennial Supplement, England and Wales. Series DS no 1. London: HMSO, 1978.

37 Office of Population Censuses and Surveys. Occupational mortality 1979-1980, 1982-1983 Decennial Supplement, England and Wales. Series no 6. London: HMSO, 1986.

38 Logan WPD. Cancer mortality by occupation and social class 1851-1971. IARC-WHO Scientific Publications no 36. Studies on medical and population subjects no 44 . London: HMSO, 1982

39 Correa P, Cuello C, Duque E, et al. Gastric cancer in Colombia. III. Natural history of precursor lesions. $\mathcal{f} \mathrm{Natl}$ Cancer Inst 1976; 57: 1027-35. 